\title{
Comparative analysis of soil magnetic susceptibility and concentration of rare earth elements in soil of problematic areas
}

doi:10.2478/mape-2019-0008

Date of submission to the Editor: 04/2018

Date of acceptance by the Editor: 07/2018

MAPE 2019, volume 2, issue 1, pp. 81-90

\section{Jarosław Zawadzki*}

ORCID ID: 0000-0003-2842-0018

ID K-4740-2012

Piotr Fabijańczyk

ORCID ID: 0000-0002-0769-2324

Warsaw University of Technology, Poland

\section{INTRODUCTION}

The group of rare earth elements (REE) include the lanthanide elements, Sc and Y. Usually two groups of REE elements are distinguished. The first one includes the La, $\mathrm{Ce}, \mathrm{Pr}, \mathrm{Nd}, \mathrm{Sm}$, Eu and is called light REE. The remaining REEs are included in the group called heavy REE such. The important characteristic of all REE is that they have very similar physical and chemical properties (Hu et al., 2006). Moreover, all REE are often found in the same type of ores.

The REE and their compounds are very important for industry mostly because of their magnetic properties. Without the REE production of permanent magnets that are part of disc drives and many important electronic parts and batteries would be impossible (Jarosiński, 2016). Because of that, REE have been recognized as resources critical for today industry, because the lack of possibility of their substitution (Seredin and Dai, 2012). REE are characterized by limited amounts of ores, and moreover REE are usually highly dispersed in their minerals. Usually, REE are obtained from ores like bastnaesite, monazite and laterite. At present the majority of ores is located in countries such as China, USA, and India. In Poland, the natural resources of REE are rather small, and REE ores, such as: monacite, xenotile, apatite and zirconium are found mostly in Lower Silesia region, especially near Szklarska Poręba town, and near Białystok town, in a form of carbonatite (Kowalczyk \& Mazanek, 1989).

Numerous studies were carried out so far that aimed at the analysis of potential secondary sources of REE. As it was analyzed, significant amounts of REE can be found in phosphogypsum, electrical and electronic waste or used catalytic converters (Jarosiński, 2016). The most important secondary source of REE is scrap electronic parts, and especially permanent magnets, $\mathrm{Fe}_{14} \mathrm{Nd}_{2} \mathrm{~B}$ or $\mathrm{Sm}_{2} \mathrm{Co}_{5}$. As it was found the content of $\mathrm{Nd}$ in this type of magnets can reach up to $24 \%$, and Dy levels are up to about $5 \%$.

What is important in highly industrialized areas significant concentrations of REE can be found in fly ash produced during the combustion of hard coal (Jarosiński, 2016;

*j.j.zawadzki@gmail.com 
Smółka-Danielowska D., 2007). This observation can be important for southern part of Poland where substantial part of the industry is based on the coal extraction or coal combustion. As it was studied, after the dusts containing REE are deposited on the soil surface they are accumulated in organic and humic soil layers, similarly like other pollutants (Cao, et al. 2001). The rate of adsorption of REE in soil depends on $\mathrm{pH}$ and soil cation exchange capacity. The availability of REE usually increases with a decrease of $\mathrm{pH}$ and redox potential. Concentrations of REE in soil was also found to be dependent on a presence of organic material and chemical and physical properties of soil (Ran and Liu, 1993; Beckwith \& Bulter, 1993). What is important the studies related to the analysis of REE concentration in soil that results from coal-based industry is still limited.

The important characteristics of REE concentration in soil that result from coal-based industry it that technogenic particles contain also admixtures of ferromagnetic elements as $\mathrm{Fe}, \mathrm{Co}$, or $\mathrm{Ni}$, and reveal strong magnetic properties that can be measured and analyzed using soil magnetometry. As it was presented in numerous studies (Thompson et al. 1980; Strzyszcz et al. 1996; Petrovsky et al., 2000; Spiteri et al., 2005; Magiera \& Zawadzki, 2006, 2007; Fürst et al., 2009; Zawadzki et al., 2009; Fabijańczyk et al., 2017) increased concentration of technogenic particles can be determined in soil using several geophysical methods. One of them is soil magnetometry that is a sophisticated technique of detecting and determining the level of potential soil pollution with anthropogenic dusts that are emitted by various types of industry (Ayoubi et al., 2013, 2018a, 2018b). Most of magnetometric studies were focused on the determination of soil pollution with heavy metals or Potentially Toxic Elements. Commonly, soil magnetic susceptibility $\mathrm{K}$ is measured using the Bartington MS2 Magnetic Susceptibility System, equipped with various sensors (Dearing, 1994). In the paper the possibility of using magnetometric measurements to delineate the areas with elevated concentrations of REE in soils of highly industrialized regions was investigated. To do so, three significantly different study areas were selected for field measurements, which were located in northern, and southern Norway, and in Upper Silesian Industrial Area. The analysis of concentrations of REE in soil was based on the chemical measurements and soil samples that were collected in study areas. Also, magnetometric measurements were carried out which allowed for investigation potential correlations between soil magnetic susceptibility and concentrations of REE in soil.

\section{METHODOLOGY OF RESEARCH}

At the beginning, three distinctly different areas were carefully selected, which could be called "problematic" because of higher level of anthropogenic pollution or a specific geological background. It is worth to mention here that all field measurements and laboratory analyses were performed in the frame of the Polish-Norwegian Research Grant entitled "Development of integrated geophysical/geochemical methods of soil and groundwater pollution assessment and control in problematic areas" (the acronym IMPACT) carried out in 2009-2014. The first one was located in Piekary Śląskie, Upper Silesian Industrial Area, south Poland, in the direct vicinity of the lead ore and lead battery processing factory, about $700 \mathrm{~m}$ away from a heap of metallurgical wastes. In this waste heap, high concentrations of sulphides of $\mathrm{Hg}$, Be, $\mathrm{Cu}, \mathrm{Ag}$, Se, as well as many REE were found. Consequently, the soils of this area 
were subjected to pollution by dust generated by the sulphidation processes of the sulphides contained in the waste heap. Subsequently, these dusts were transported by winds to neighboring areas, including the field being investigated.

Second area was located in northern Norway, above the Arctic Circle near the border with Russia. This area is very polluted due to the nearby location of the mining industry that has been developing there for about 80 years. The main industrial facility was a Bjornevatn mine dealing with iron ore mining. During the mining of iron ores, significant amounts of waste are generated which is the cause of strong anthropogenic pressure on the environment (Bronder et al., 2010). Two main soil types were observed in the study area. Leptosols, shallow soils formed on hard rock or gravel material and have a low water retention capacity (Jones et al., 2010). In this area the magnetic signal is due to fine-grained primary sulphides and secondary finegrained magnetite and/or maghemite (Magiera et al., 2018).

The third area was located in the southern Norway between Lyngdal and Moi villages. This area was not subjected to the significant local anthropogenic pressure though the geological background was composed of granite bedrock. In a consequence, soils of this area were characterized by significantly high magnetic background. Some studies also suggest that this part of Norway may be subjected to long-range pollution (Steinnes \& Friedland, 2006).

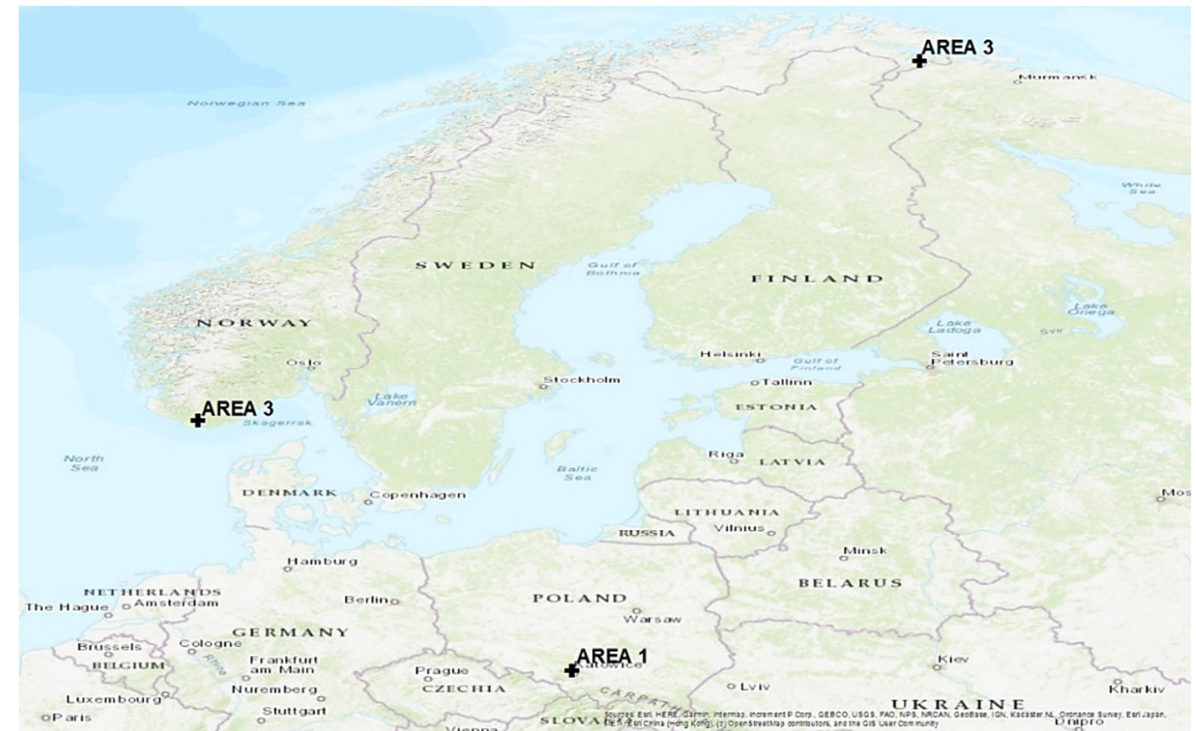

Fig. 1 Study area with marked location of measurement sites

At each study area about 15 soil cores were collected. Soil cores, $30 \mathrm{~cm}$ long, were taken to plastic tubes using a Humax sampler. Soil samples used to determine the content of selected REE in the soil were cut from a depth of $0 \mathrm{~cm}$ to $10 \mathrm{~cm}$ below the soil surface. Next, soil samples were dried, homogenized and sieved through a $2 \mathrm{~mm}$ sieve to separate the soil skeleton. Then, about $250 \mathrm{mg}$ of the dried soil sample was digested with $50 \%(\mathrm{v} / \mathrm{v}) \mathrm{HNO}_{3}$, placed in a Teflon bottle, diluted to $108 \mathrm{ml}$ and transferred to $15 \mathrm{ml}$ vials for ICP-MS analysis.

Mass specific magnetic susceptibility $x$ was calculated using collected soil cores. Firstly, soil subsamples were cut from this part of collected soil cores, where maximum value of $\mathrm{k}$ was measured. Next, magnetic susceptibility of these subsamples was measured using a MS2B Bartington sensor (Dearing, 1994). 

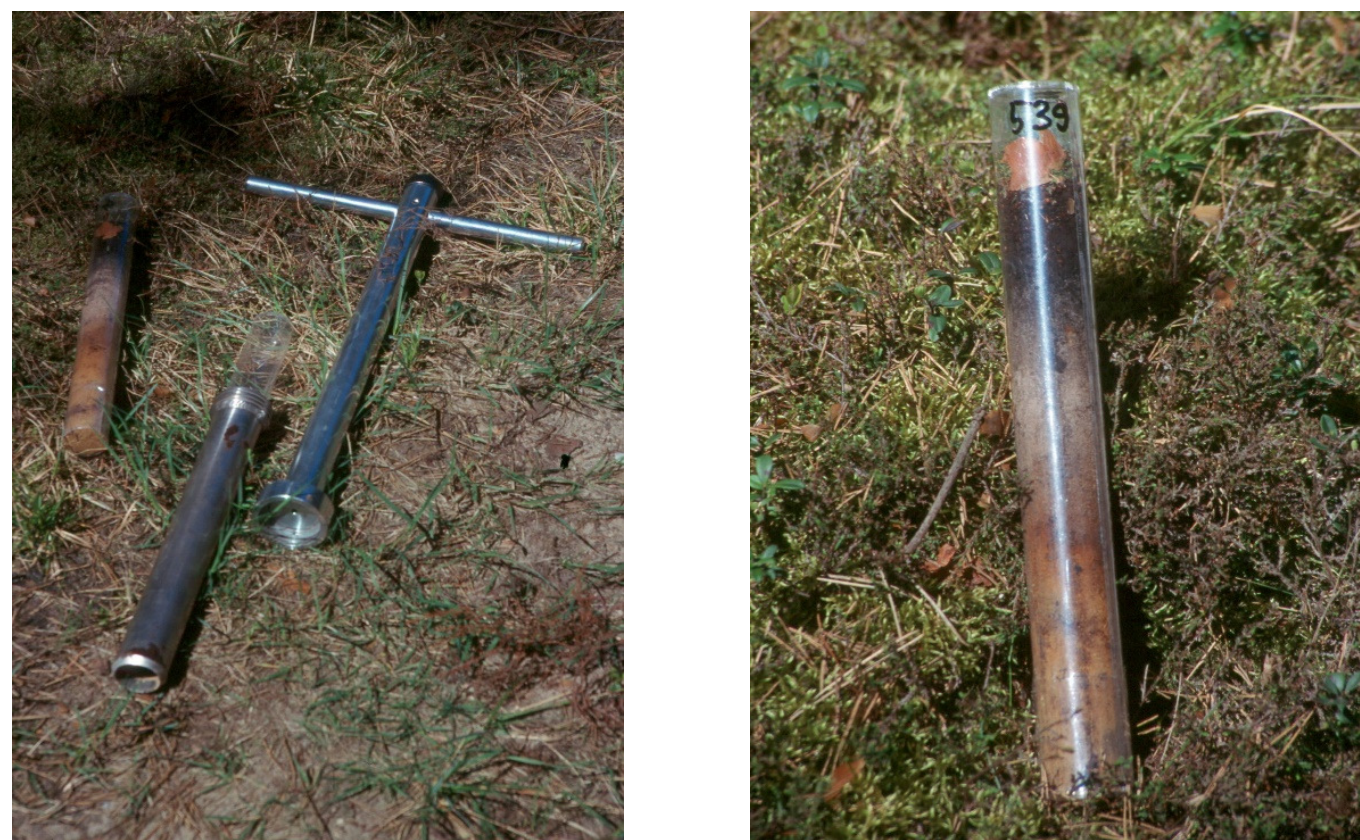

Fig. 2 a) Humax sampler, b) $\mathbf{3 0} \mathbf{c m}$ length soil profile taken using Humax sampler Source: (Magiera, Zawadzki, 2006).

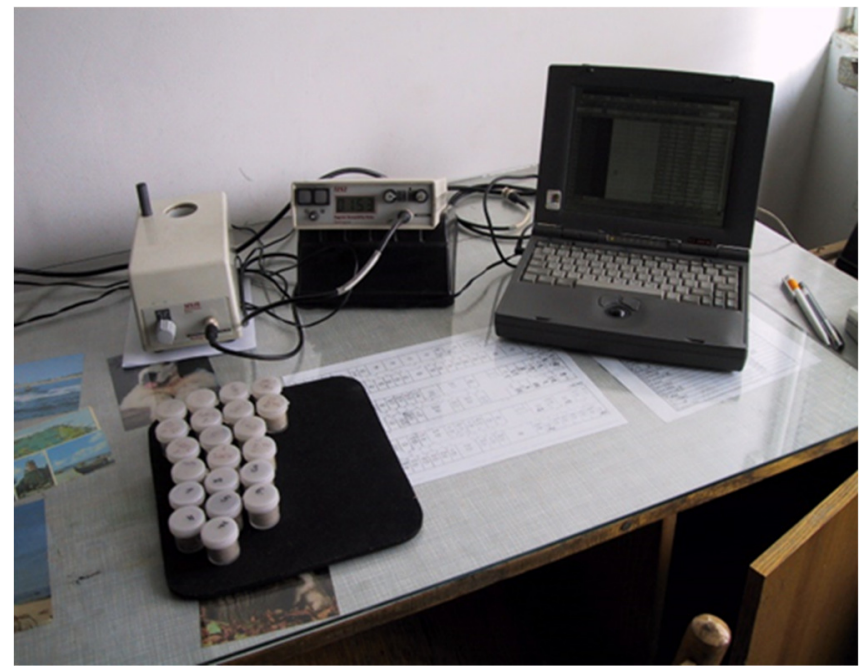

Fig. 3 Laboratory system with a MS2B Bartington device for magnetic susceptibility measurements

Source: (Magiera, Zawadzki, 2006)

The MS2B sensor had a resolution equal to $2 \times 10^{-6} \mathrm{SI}$ and its calibration accuracy was equal to $1 \%$. The mass specific magnetic susceptibility $X$ of each soil subsample was calculated using soil subsamples with a volume of $10 \mathrm{~cm}^{3}$. Consequently, the calculation of mass-specific susceptibility was done by multiplication by $10 \mathrm{~cm}^{3}$ and division by the actual mass of the soil sample, irrespective of its actual volume.

\section{RESULTS AND DISCUSSION}

Concentrations of REE in soils were previously studied, and typical concentrations of REE in soil were determined (Ramos et al., 2016). These values, separately for Poland and Norway were presented in the Table 1. 
Table 1

Typical concentrations of REE in soils of Poland and Norway

\begin{tabular}{|c|c|c|}
\hline & \multicolumn{2}{c|}{ Poland $[\mathrm{mg} / \mathrm{kg}]$} \\
\hline Ce & $5.5-72$ & $5.7-253$ \\
\hline Dy & $0.4-5.1$ & $0.8-9$ \\
\hline Er & $0.3-3.1$ & $0.6-5.0$ \\
\hline Ho & $0.1-1.0$ & $0.9-1.8$ \\
\hline La & $2.7-35$ & $2.9-101$ \\
\hline Lu & $0.05-0.5$ & $0.1-0.8$ \\
\hline Nd & $2.3-30$ & $2.8-80$ \\
\hline Pr & $0.7-8.0$ & $2.8-80$ \\
\hline Sc & $0.7-12$ & $2.5-33$ \\
\hline Sm & $0.4-5.5$ & $0.5-13$ \\
\hline Tb & $0.05-0.8$ & $0.1-1.7$ \\
\hline Tm & $0.05-0.5$ & $0.09-0.8$ \\
\hline Y & $14-30$ & - \\
\hline Yb & $0.3-3.4$ & $0.6-5.8$ \\
\hline Rm & & \\
\hline
\end{tabular}

Source: (Ramos et al., 2016)

As it was observed, in the area located near the battery processing factory (Area 1) measured average concentrations of all REE (Table 2) in soils were within the typical ranges observed in previous studies (Table 1). Similar observation was made in the case of the area 3, where the soils were developed on the granite bedrock.

In the area that was located in the vicinity of the Bjornevatn iron ore exploration factory. It was observed that the average measured concentrations of REE in this area were closer to a lower boundary of the interval of typical concentrations (Table 1). In the case of $\mathrm{Pr}, \mathrm{Ho}$, and $\mathrm{Lu}$, the average measured concentrations in soil were even lover than a usually observed concentration that were determined in previous studies.

As it was previously observed during comparison with typical REE concentrations in soil, the lowest concentrations of all REE were observed in the area located in the vicinity of iron ore exploration factory. Simultaneously, in this area calculated values of mass magnetic susceptibility of soil were high, with maximum values reaching over $800 \times 10-3 \mathrm{~m}^{3} / \mathrm{kg}$. Average measured mass magnetic susceptibility in this area was equal to about $306 \times 10-3 \mathrm{~m}^{3} / \mathrm{kg}$. Such observation suggest that soil was potentially polluted or, what was also evident in this area, increased magnetic susceptibility of soil resulted from natural properties of geological substrata and presence of iron ores. Strong influence on the natural background values of soil magnetic susceptibility was observed in the area 3, where granite bedrock was present. The calculated values of mass magnetic susceptibility in this area were very high, up to $1600 \times 10-3 \mathrm{~m}^{3} / \mathrm{kg}$. Such extreme values might suggest the extreme soil pollution, however in the area 3 anthropogenic pressure was low, and very high magnetic susceptibility of soil was a result of properties of granite rock. As it was observed, also the concentrations of REE in this area were the highest of all study areas. As it could be expected, geological bedrock in this area was characterized by some, increased amounts of REE. 
Table 2

Descriptive statistics of REE concentrations in soil, and mass magnetic susceptibility in study areas 1 and 2

\begin{tabular}{|c|c|c|c|c|c|c|c|}
\hline & & Average & Minimum & Maximum & Q25\% & Q75\% & Std. Dev. \\
\hline \multirow{15}{*}{ 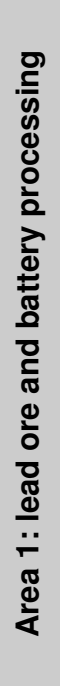 } & $x$ & 162 & 8 & 295 & 107 & 237 & 78 \\
\hline & $\mathrm{Ce}$ & 39.31 & 31.09 & 50.16 & 34.15 & 44.26 & 5.52 \\
\hline & Dy & 2.02 & 1.47 & 2.72 & 1.73 & 2.42 & 0.37 \\
\hline & $\mathrm{Er}$ & 1.03 & 0.68 & 1.43 & 0.87 & 1.23 & 0.21 \\
\hline & Ho & 0.36 & 0.25 & 0.5 & 0.3 & 0.43 & 0.07 \\
\hline & La & 18.58 & 14.66 & 23.71 & 16.66 & 20.84 & 2.4 \\
\hline & Lu & 0.12 & 0.09 & 0.17 & 0.11 & 0.15 & 0.02 \\
\hline & Nd & 16.56 & 13.31 & 21.48 & 14.24 & 18.98 & 2.31 \\
\hline & $\operatorname{Pr}$ & 4.37 & 3.49 & 5.73 & 3.8 & 4.95 & 0.62 \\
\hline & Sc & 4.02 & 2.51 & 6.96 & 3.33 & 4.72 & 0.93 \\
\hline & $\mathrm{Sm}$ & 3.14 & 2.42 & 4.18 & 2.76 & 3.64 & 0.47 \\
\hline & $\mathrm{Tb}$ & 0.35 & 0.26 & 0.48 & 0.29 & 0.41 & 0.06 \\
\hline & $\mathrm{Tm}$ & 0.13 & 0.09 & 0.19 & 0.11 & 0.16 & 0.03 \\
\hline & $\mathbf{Y}$ & 9.44 & 6.21 & 12.98 & 8.17 & 11.07 & 1.82 \\
\hline & $\mathrm{Yb}$ & 0.86 & 0.58 & 1.15 & 0.72 & 1.04 & 0.16 \\
\hline \multirow{15}{*}{ 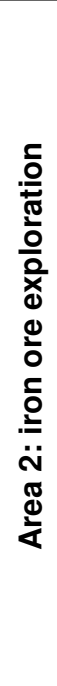 } & $x$ & 306 & 2 & 887 & 109 & 533 & 245 \\
\hline & $\mathrm{Ce}$ & 8.04 & 1.21 & 21.49 & 5.37 & 10.05 & 5.24 \\
\hline & Dy & 0.8 & 0.08 & 1.9 & 0.45 & 1.06 & 0.54 \\
\hline & Er & 0.49 & 0.05 & 1.16 & 0.28 & 0.7 & 0.3 \\
\hline & Ho & 0.16 & 0.01 & 0.39 & 0.09 & 0.22 & 0.11 \\
\hline & La & 4.16 & 0.66 & 14.41 & 2.74 & 4.89 & 3.23 \\
\hline & Lu & 0.06 & 0.01 & 0.15 & 0.03 & 0.09 & 0.04 \\
\hline & Nd & 4.38 & 0.59 & 17.51 & 2.7 & 4.98 & 4.01 \\
\hline & $\mathrm{Pr}$ & 1.08 & 0.15 & 4.17 & 0.67 & 1.2 & 0.95 \\
\hline & Sc & 4.09 & 0.29 & 11.07 & 2.16 & 5.46 & 2.82 \\
\hline & Sm & 0.86 & 0.12 & 3.12 & 0.5 & 1.13 & 0.73 \\
\hline & $\mathrm{Tb}$ & 0.13 & 0.02 & 0.35 & 0.08 & 0.18 & 0.09 \\
\hline & $\mathrm{Tm}$ & 0.07 & 0.01 & 0.17 & 0.03 & 0.1 & 0.04 \\
\hline & $Y$ & 4.19 & 0.47 & 9.55 & 2.41 & 5.93 & 2.64 \\
\hline & $\mathbf{Y b}$ & 0.4 & 0.04 & 0.98 & 0.23 & 0.58 & 0.25 \\
\hline
\end{tabular}

As it was observed in all studied areas statistically significant correlations were observed between mass magnetic susceptibility and the concentrations of all REE in soil. The strength of these correlations was the lowest in the area located near the iron ore processing factory. Such observation was related to very high concentration of iron ores that can be characterized by strong magnetic properties. In a consequence, the magnetic signal of REE ores or compounds could be too weak to be detected using measurements of soil magnetic susceptibility.

In the area with low anthropogenic pressure, where soils were developed on the granite bedrock, high and significant correlations between mass magnetic susceptibility and the concentrations of all REE were observed. Such observation suggested that soil magnetic susceptibility can be used as an indicator of increased concentrations of REE also in areas with low pollution, but with natural presence of ores. 
Table 3

Descriptive statistics of REE concentrations in soil, and mass magnetic susceptibility in study area 3

\begin{tabular}{|c|c|c|c|c|c|c|c|}
\hline & & Average & Minimum & Maximum & Q25\% & Q75\% & Std. Dev. \\
\hline \multirow{15}{*}{ 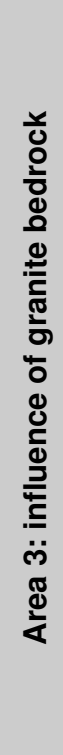 } & $x$ & 986 & 129 & 1561 & 814 & 1236 & 369 \\
\hline & $\mathrm{Ce}$ & 55.95 & 8.65 & 155.95 & 24.76 & 82.5 & 37.6 \\
\hline & Dy & 2.51 & 0.43 & 5.1 & 1.23 & 3.16 & 1.37 \\
\hline & $\mathrm{Er}$ & 1.3 & 0.22 & 2.56 & 0.69 & 1.57 & 0.71 \\
\hline & Ho & 0.45 & 0.08 & 0.9 & 0.23 & 0.56 & 0.25 \\
\hline & La & 19.15 & 3.47 & 53.92 & 9.91 & 25.58 & 11.86 \\
\hline & Lu & 0.15 & 0.03 & 0.29 & 0.09 & 0.19 & 0.08 \\
\hline & Nd & 20.08 & 3.29 & 55.7 & 10.43 & 25.42 & 12.21 \\
\hline & Pr & 5.34 & 0.89 & 15.12 & 2.7 & 7.17 & 3.28 \\
\hline & Sc & 2.6 & 0.63 & 5.65 & 1.47 & 3.58 & 1.37 \\
\hline & Sm & 3.55 & 0.57 & 8.85 & 1.84 & 4.31 & 2.07 \\
\hline & $\mathrm{Tb}$ & 0.42 & 0.07 & 0.86 & 0.21 & 0.51 & 0.23 \\
\hline & $\mathrm{Tm}$ & 0.18 & 0.03 & 0.35 & 0.09 & 0.22 & 0.1 \\
\hline & $\mathbf{Y}$ & 11.12 & 1.93 & 23.48 & 5.94 & 13.68 & 6.11 \\
\hline & $\mathrm{Yb}$ & 1.12 & 0.18 & 2.18 & 0.59 & 1.34 & 0.59 \\
\hline
\end{tabular}

In the vicinity of lead ore and battery processing factory between mass magnetic susceptibility and the concentrations of all REE were equal to about 0.5-0.6, and for most of REE were statistically significant. The reason for so evident correlations could be significant amounts of dust blown from the waste heap after battery postprocessing. The distance from the study area to this waste heap was low, and equal to about $700 \mathrm{~m}$.

Table 4

Pearson's and Spearman's correlation coefficients between mass magnetic susceptibility and REE concentrations in soil in study areas 1, 2, and 3; marked coefficients are statistically significant at $\alpha=0.05$

\begin{tabular}{|c|c|c|c|c|c|c|}
\hline \multicolumn{2}{|c|}{$\begin{array}{c}\text { Area 1: lead ore and battery } \\
\text { processing }\end{array}$} & \multicolumn{2}{c|}{$\begin{array}{c}\text { Area 2: iron ore } \\
\text { exploration }\end{array}$} & \multicolumn{2}{c|}{$\begin{array}{c}\text { Area 3: influence of } \\
\text { granite bedrock }\end{array}$} \\
\hline & Pearson's & Spearman's & Pearson's & Spearman's & Pearson's & Spearman's \\
\hline Ce & $\mathbf{0 . 3 6}$ & 0.12 & 0.51 & 0.19 & $\mathbf{0 . 7 0}$ & $\mathbf{0 . 6 8}$ \\
\hline Dy & $\mathbf{0 . 6 4}$ & $\mathbf{0 . 6 3}$ & 0.42 & 0.25 & $\mathbf{0 . 7 9}$ & $\mathbf{0 . 7 5}$ \\
\hline Er & $\mathbf{0 . 6 3}$ & $\mathbf{0 . 5 5}$ & 0.29 & 0.32 & $\mathbf{0 . 7 9}$ & $\mathbf{0 . 7 5}$ \\
\hline Ho & $\mathbf{0 . 6 1}$ & $\mathbf{0 . 5 2}$ & 0.35 & 0.27 & $\mathbf{0 . 7 9}$ & $\mathbf{0 . 7 4}$ \\
\hline La & 0.34 & 0.17 & $\mathbf{0 . 5 9}$ & 0.10 & $\mathbf{0 . 7 2}$ & $\mathbf{0 . 6 8}$ \\
\hline Lu & $\mathbf{0 . 6 1}$ & $\mathbf{0 . 5 4}$ & 0.17 & 0.25 & $\mathbf{0 . 7 9}$ & $\mathbf{0 . 7 2}$ \\
\hline Nd & 0.28 & 0.21 & $\mathbf{0 . 6 0}$ & 0.14 & $\mathbf{0 . 7 6}$ & $\mathbf{0 . 7 2}$ \\
\hline Pr & 0.21 & 0.16 & $\mathbf{0 . 6 0}$ & 0.16 & $\mathbf{0 . 7 4}$ & $\mathbf{0 . 7 2}$ \\
\hline Sc & $\mathbf{0 . 5 1}$ & $\mathbf{0 . 4 9}$ & -0.08 & 0.06 & $\mathbf{0 . 4 8}$ & $\mathbf{0 . 5 3}$ \\
\hline Sm & $\mathbf{0 . 3 7}$ & 0.31 & $\mathbf{0 . 5 8}$ & 0.24 & $\mathbf{0 . 7 7}$ & $\mathbf{0 . 7 1}$ \\
\hline Tb & $\mathbf{0 . 5 8}$ & $\mathbf{0 . 5 1}$ & 0.47 & 0.28 & $\mathbf{0 . 7 9}$ & $\mathbf{0 . 7 3}$ \\
\hline Tm & $\mathbf{0 . 5 8}$ & $\mathbf{0 . 5 2}$ & 0.22 & 0.29 & $\mathbf{0 . 8 0}$ & $\mathbf{0 . 7 4}$ \\
\hline Y & $\mathbf{0 . 6 9}$ & $\mathbf{0 . 6 3}$ & 0.37 & 0.29 & $\mathbf{0 . 8 1}$ & $\mathbf{0 . 7 6}$ \\
\hline Yb & $\mathbf{0 . 5 4}$ & $\mathbf{0 . 4 4}$ & 0.18 & 0.22 & $\mathbf{0 . 7 9}$ & $\mathbf{0 . 7 4}$ \\
\hline
\end{tabular}




\section{CONCLUSIONS}

The weakest correlations between soil magnetic susceptibility and concentrations of REE were observed in the vicinity of iron ore exploration factory in Bjornevatn (Area 2). There can be two possible explanations of such observation, one is low concentrations of REE in soil of this area, and the second is strong magnetic signal from the iron ores. In the area located near a factory of lead ore and battery processing (Area 1) concentrations of most of REE were significantly correlated with soil magnetic susceptibility. The highest correlations coefficients between soil magnetic susceptibility and concentrations of REE were found in the area where soils were developed on the bedrock with strong natural magnetic background with the influence of granite rock (Area 3). Analysing the above results it can be concluded that the origins of observed dependencies could be complicated or even indirect, and that these results based on macroscopic level measurements need to be checked by studies at microscopic scale. On the other hand, the obtained values of Pearson's and Spearman's correlations coefficients were often unsuspectedly high. However, more systematic studies including e.g. the use of geostatistical methods and geochemical indicators, especially carried out on anthropogenically polluted soils with REE are necessary to confirm the observed dependencies.

\section{ACKNOWLEDGEMENT}

The research leading to collecting the samples and making measurements has received funding from the Polish-Norwegian Research Programme operated by the National Centre for Research and Development under the Norwegian Financial Mechanism 2009-2014 in the frame of Project IMPACT - Contract No PolNor/199338/45/2013. The Project IMPACT was coordinated by prof. Tadeusz Magiera from the Institute of Environmental Engineering of Polish Academy of Sciences to whom authors want especially to thank for unceasing help and collaboration in experimental part of the study.

The analytical part of the work was carried out in frame of the statutory activities of the Department of Building Installations, Hydrotechnics and Environmental Engineering of the Warsaw University of Technology.

\section{REFEENCES}

Beckwith, R., Bulter, J. (1993). Aspects of the chemistry of soil organic matter. In soils, An Australian Viewpoint. Division of Soils. CSIRO. Australia: Canberra,.

Bronder, L., Kudrik, I., Nikitin, A., Jorgensen, K.V. and Nikiforov V. (2010). Environmental Challenges in the Arctic, Norilsk Nickel. The Soviet Legacy of Industrial Pollution. Bellona report.

Cao, X. (2001). Effects of redox potential and $\mathrm{pH}$ value on the release of rare earth elements from soil. Chemosphere, 44, pp. 655-661.

Dai, S.F., Zoua, J., Jiang, Y., Ward, C.R., Wang, X., Li, T., Xue, W., Liu, Sh., Tian, H., Sun, X. and Zhou, D. (2012). Mineralogical and geochemical compositions of the Pennsylvanian coal in the Adaohai Mine, Daqingshan Coalfield, Inner Mongolia, China: Modes of occurrence and origin of diaspore, gorceixite and ammonianillite. International Journal of Coal Geology, 94, pp. 250-270.

Dearing, J.A. (1994). Environmental Magnetic Susceptibility. Using the Bartington MS2 System. Chi Publishing. UK: Kenilworth.

Fabijańczyk, P., Zawadzki, J. and Magiera T. (2017). Magnetometric assessment of soil contamination in problematic area using empirical Bayesian and indicator kriging: A case study in Upper Silesia. Poland. Geoderma, 308, pp. 69-77. 
Fürst, Ch., Lorz, C. and Makeschin, F. (2009). Testing a Soil Magnetometry Technique in a Highly Polluted Industrial Region in North-Eastern Germany. Water Air Soil Poll, 202(14), pp. 33-43.

Hower, J.C., Ruppert, L.F., Eble, C.F. (1999). Lanthanide, yttrium, and zirconium anomalies in the Fire Clay coal bed. Eastern Kentucky. International Journal of Coal Geology, 39, pp. 141-153.

Hu, Z., Haneklaus, S., Sparovek, G. and Schnug, E. (2006). Rare earth elements in soil. Communications in Soil Science and Plant Analysis, 37, pp. 1381-1420.

Jarosiński, A. (2016). Możliwości pozyskiwania metali ziem rzadkich w Polsce. Zeszyty Naukowe, Instytutu Gospodarki Surowcami Mineralnymi i Energią, Polskiej Akademii Nauk, 92, pp. 75-88.

Jones, A., Montanarella, L., Micheli, E., Spaargaren, O. and Jones, R.J.A. (2010). Major soil types of Europe. European Commission Joint Research Centre. R. Salminen, M. Batista, J. Bidovec, M. Demetriades, A. et al. Geochemical atlas of Europe. Part 1: Background information, methodology and maps.

Kowalczyk, J., Mazanek, C. (1989). Metale ziem rzadkich i ich związki. Warszawa: WNT.

Ramos, S.J., Dinali, G.S., Oliveira, C. et al., (2016). Rare Earth Elements in the Soil. Environment Curr Pollution Rep, 2, pp. 28-50.

Magiera, T., Zawadzki, J., (2006). Magnetometria glebowa - nowe narzędzie geofizyczne do oceny zanieczyszczenia gleb. Geofizyka. Biuletyn Informacyjny, 2(2006), pp. 74-90.

Magiera, T., Zawadzki, J. (2007). Using of high-resolution topsoil magnetic screening for assessment of dust deposition: comparison of forest and arable soil datasets. Environ. Monit. Assess., 125, pp. 19-28.

Magiera, T., Zawadzki, J. , Szuszkiewicz, M. , Fabijańczyk, P. , Steinnes, E. , Fabian K., Miszczak E. (2018). Impact of an iron mine and a nickel smelter at the Norwegian/Russian border close to the Barents Sea on surface soil magnetic susceptibility and content of potentially toxic elements. Chemosphere, 195, pp. 48-62.

Petrovský, E., Kapička, A., Jordanova, N., Knab, M., Hoffmann, V. (2000). Low-field magnetic susceptibility: a proxy method of estimating increased pollution of different environmental systems. Environ. Geol., 39, pp. 312-318.

Ran, Y., Liu, Z. (1993). Adsobtion and desorbtion of rare earth elements on soils and synthetic oxides. Acta Scientiae Circumstantiae, 13(3), pp. 287-293.

Smółka-Danielowska D. (2007). REE w popiołach lotnych w procesie spalania węgla kamiennego w elektrowniach górnośląskiego okręgu przemysłowego. Ochrona Środowiska i Zasobów Naturalnych, 32, pp. 190-194.

Spiteri, C., Kalinski, V., Rosler, W., Hoffman, V. and Appel, E. (2005). Magnetic Screening of Pollution Hotspots in the Lausitz Area, Eastern Germany: Correlation Analysis Between Magnetic Proxies and Heavy Metal Concentration in Soil. Environ. Geol., 49, pp. 1-9.

Seredin, V.V., Dai, S. (2012). Coal deposits as potential alternative sources for lanthanides and yttrium. International. J. Coal Geol., 94, pp. 67-93.

Strzyszcz, Z., Magiera, T., Heller F. (1996). The influence of industrial immisions on the magnetic susceptibility of soils in Upper Silesia. Studia Geoph, et Geod., 40, pp. 276286.

Steinnes, E., Friedland, A.J. (2006). Metal contamination of natural surface soils from longrange atmospheric transport: existing and missing knowledge. Environ Rev.,14(3), pp. 169-186.

Thompson, R., Stober, J.C., Turner, G.M., Oldfield, F., Bloemendal, J., Dearing, J.A., Rummery, T.A. (1980). Environmental applications of magnetic measurements, Science, 207(4430), pp. 481-486.

Zawadzki, J., Fabijańczyk, P., Magiera, T. (2009). Geostatistical evaluation of magnetic indicators of forest soil contamination with heavy metals. Studia Geophysica et Geodaetica, 53(1), pp.133-149. 
Abstract: Soil contamination with rare earth metals (REE) can have both direct and indirect connection with industrial activity and ore-exploration. In the studies conducted so far, the presence of rare earth elements in coal seams, coal combustion waste as well as fly ash was found. It is important that detailed studies of the REE content in soil were not carried out in Poland. Until now, in a few studies, a high content of cerium and lanthanum was found in relation to the average content of the torn ones in the world. This work focuses on the areas under the influence of the industry associated with the extraction and combustion of hard coal, but also with other types of industry. Analyzes of REE content in soil were conducted in selected areas of the Upper Silesian Industrial Region and Norway, located near the Bjornevatn mine. In study areas, soil samples were collected and used for chemical and magnetometric measurements. Firstly, concentrations of REE were determined, and after that soil samples were used to measure soil magnetic susceptibility. Finally, statistical analyses were performed in order to check the correlation between REE concentrations in soil and soil magnetic susceptibility.

Keywords: soil pollution, rare earth elements, magnetometry, magnetic susceptibility, industrial areas 